\title{
EXPERIMENTAL INVESTIGATION OF METHYL ESTER OF COTTON SEED OIL BLEND WITH DIESEL ON CI ENGINE
}

\author{
Vijayaraj, K. and A.P. Sathiyagnanam \\ Department of Mechanical Engineering, Annamalai University, Tamilnadu, India
}

Received 2014-07-28; Revised 2014-10-20; Accepted 2014-10-28

Competing Interests: The authors have declared that no competing interests exist

\begin{abstract}
Petroleum based fuels worldwide have not only resulted in the rapid depletion of conventional energy sources, but have also caused severe air pollution. The search for an alternate fuel has led to many findings due to which a wide variety of alternative fuels are available at our disposal now. The existing studies have revealed the use of vegetable oils for engines as an alternative for diesel fuel. However, there is a limitation in using straight vegetable oils in diesel engines due to their high viscosity and low volatility. In the present work, neat cotton seed oil is converted into their respective methyl ester through transesterification process. Experiments were conducted using various blends of methyl ester of cotton seed oil with diesel in a single cylinder, four stroke vertical and air cooled Kirloskar diesel engine. The results showed higher brake thermal efficiency and lower brake specific fuel consumption for B25 when compared to other blends. There is an appreciable decrease in HC emission while the decrease in $\mathrm{CO}$ emission is marginal. However, there is an increase in the emission of $\mathrm{NO}_{\mathrm{x}}$. Reduction in smoke emission is observed for B25 at all loads, particularly there is a marked decrease of 5.4\% at full load when compared to diesel. It was observed that the combustion characteristics of the blends of methyl ester of cotton seed oil with diesel followed closely with that of the base line diesel.
\end{abstract}

Keywords: Biodiesel, Methyl Ester of Cotton Seed Oil, Performance, Emission, Combustion

\section{INTRODUCTION}

India is importing crude petroleum and petroleum products from gulf countries. Indian scientists searched for an alternate to diesel fuel to preserve the global environment and to withstand the economic crisis. As far as India is concerned because of its vast agro forestry base, fuels of bio origin can be considered to be ideal alternative renewable fuels to run the internal combustion engines. Vegetable oils from plants both edible, non-edible and methyl esters (Biodiesel) are used as an alternate source for diesel fuel. Biodiesel was found to be the best alternate fuel, technically, environmentally acceptable, economically competitive and easily available. There are more than 350 oil bearing crops that have been identified, among which only sunflower, soyabean, cottonseed, mango seed, rapeseed and peanut oils are considered as potential alternative fuels for diesel engines. Traditional oilseed feedstock for biodiesel production predominantly includes soyabean, rapeseed/canola, palm, corn, sunflower, cottonseed, peanut and coconut oil (Sylvester and Ohimain, 2013). The long chain hydrocarbon structure, vegetable oils have good ignition characteristics, however they cause serious problems such as carbon deposits build up, poor durability, high density, high viscosity, lower calorific value, more molecular weight and poor combustion. These problems lead to poor thermal efficiency, while using vegetable oil in the engine. These problems can be rectified by different methods which are used to reduce the viscosity of vegetable oils. The methods are transesterification, dilution and cracking method (Singh, Corresponding Author: Vijayaraj, K., Department of Mechanical Engineering, Annamalai University, Tamilnadu, India 
2012). The transesterification of vegetable oil gives better performance when compared to straight vegetable oil (Shereena and Thangaraj, 2009). Implementation of biodiesel in India will lead to many advantages like green cover to waste land, support to agriculture, rural economy, reduction in dependence on imported crude oil and reduction in air pollution (Jain and Sharma, 2011).

\section{BIODIESEL PRODUCTION AND CHARACTERIZATION}

\subsection{Biodiesel Production Procedure}

The biodiesel fuel used in this study was produced from the transesterification of raw cotton seed oil. The transesterification process of cotton seed oil was performed using $13 \mathrm{gm}$ of potassium hydroxide and $250 \mathrm{~mL}$ of methanol per litre of raw cotton seed oil. First, raw cotton seed oil was taken in a container and stirred with a mechanical stirrer and simultaneously heated with the help of a heating coil. The speed of the stirrer should be minimal till the temperature of the raw oil reaches $55^{\circ} \mathrm{C}$. Then, $\mathrm{KOH}$ was mixed with methanol separately in a beaker and stirred until they were properly dissolved. The solution was then added to the preheated cotton seed oil in the reactor and the reactor was closed with air tight lid. Now the solution was stirred at high speed of $650 \mathrm{rpm}$, care should be taken that the temperature does not exceed $60^{\circ} \mathrm{C}$ as methanol evaporates at temperature of $65^{\circ} \mathrm{C}$. Also the $\mathrm{KOH}$-alcohol solution was mixed with cotton seed oil only at $55^{\circ} \mathrm{C}$ because heat generated when $\mathrm{KOH}$ alcohol were mixed together and the temperature of the raw oil should be more than this when the mixing was done if the reactions have to take place properly. After the mixture was stirred for $30 \mathrm{~min}$ at a fixed temperature of $60^{\circ} \mathrm{C}$, the solution was transferred to a glass container where the separation of glycerin takes place and allowed to settle down for $15 \mathrm{~h}$.

Now the methyl ester of cotton seed oil (biodiesel) gets collected in the upper portion of the glass container, whereas glycerin gets collected at the bottom portion and drain the bottom layer containing glycerin. Then the biodiesel was washed with water, again glycerin gets separated from the biodiesel and therefore removed. Again biodiesel was washed with water repeatedly for 4 to 5 times at a time interval of 1 hr until no glycerin was left in the biodiesel. Now the biodiesel was heated at $103^{\circ} \mathrm{C}$ to $105^{\circ} \mathrm{C}$ in order to remove the water contained in it. Finally, the produced Methyl Ester of Cotton Seed Oil (MECSO) was left to cool down and was ready for use. A maximum of $800 \mathrm{~mL}$ methyl ester of cotton seed oil (biodiesel) production was observed for 1 litre of raw cotton seed oil, $250 \mathrm{~mL}$ of methanol and $13 \mathrm{gm}$ of potassium hydroxide at $60^{\circ} \mathrm{C}$.

\subsection{Biodiesel Properties}

A series of tests were conducted to characterize the properties and compositions of the produced biodiesel. The properties and compositions of biodiesel and its blends with diesel fuel are shown in Table 1 and 2 respectively. It is shown that the viscosity of biodiesel is evidently higher than that of diesel fuel. The density of the biodiesel is approximately $8.16 \%$ higher than that of diesel fuel. The gross calorific value is approximately $9.12 \%$ lower than that of diesel. Therefore, it is necessary to increase the fuel amount to be injected into the combustion chamber to produce the same amount of power. Fuels with flash point $52^{\circ} \mathrm{C}$ are regarded as safe.

Thus, biodiesel is an extremely safe fuel to handle when compared to diesel. B25 has a flash point much above that of diesel; making biodiesel a preferable choice as far as safety is concerned. With the increase of biodiesel percentage in blends, solidifying point of blends increases (Qi et al., 2009).

\section{EXPERIMENT}

\subsection{Equipment and Method}

The engine Kirloskar TAF 1 was used in the experiment and its specification are shown in Table 3. The layout of the experimental setup is shown in Fig. 1. An eddy current dynamometer was connected with the engine and used to measure engine power. An exhaust gas analyser MRU DELTA 1600-L was employed to measure $\mathrm{NO}_{\mathrm{x}}, \mathrm{HC}, \mathrm{CO}, \mathrm{O}_{2}$ and $\mathrm{CO}_{2}$ emission on line. To ensure the measured values were high, the gas analyser was calibrated before each measurement using reference gases. The AVL smoke meter was used to measure the smoke density. The smoke meter was also allowed to adjust its zero point before each measurement. The AVL combustion analyser was used to measure the combustion characteristics of the engine.

\subsection{Engine Test Procedure}

The experiments were carried out by using diesel as the base line fuel (B0), $25 \%$ biodiesel $+75 \%$ diesel (B25), $50 \%$ biodiesel $+50 \%$ diesel (B50), $75 \%$ biodiesel $+25 \%$ diesel (B75) and 100\% neat biodiesel (B100) at different loads from $0 \%$ to $100 \%$ of rated engine load in 
steps of $25 \%$. Before running the engine to a new fuel, it was allowed to run for sufficient time to consume the remaining fuel of the previous experiment.

To evaluate the performance parameters, the important operating parameters such as engine speed, power output, fuel consumption, exhaust emissions and cylinder pressure were measured. Significant engine performance parameters such as Brake Specific Fuel Consumption (BSFC) and Brake Thermal Efficiency (BTE) for biodiesel and its blends were calculated.

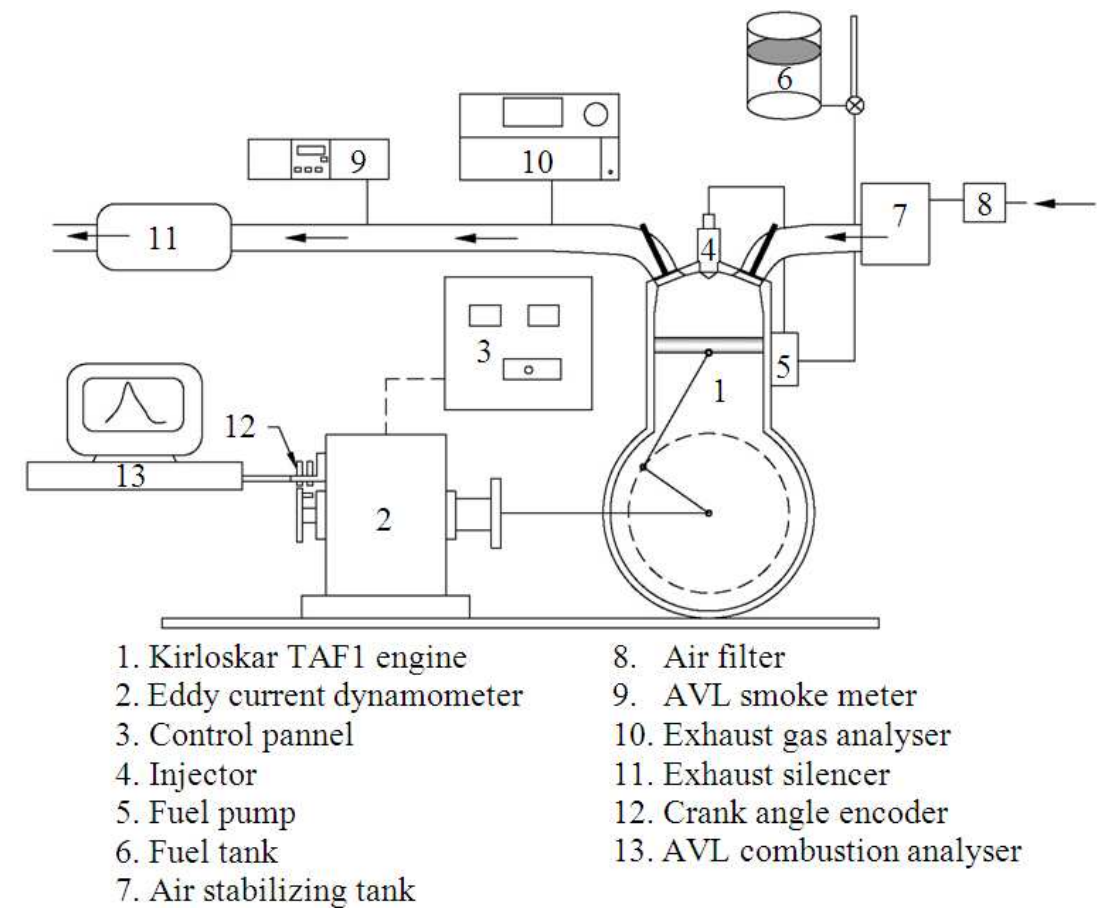

Fig. 1. Layout of experimental setup

Table 1. Properties of biodiesel in comparison with diesel and best blend

\begin{tabular}{lrrr}
\hline Property & Diesel & B 25 & B 100 \\
\hline Specific gravity @ $15^{\circ} \mathrm{C}$ & 0.8290 & 0.8459 & 0.8965 \\
Kinematic viscosity @ 40 ${ }^{\circ} \mathrm{C}$ in cSt & 2.5700 & 3.3800 & 5.8000 \\
Density @ $15^{\circ} \mathrm{C}\left(\mathrm{kg} / \mathrm{m}^{3}\right)$ & 828.1000 & 845.0000 & 895.7000 \\
Flash point ${ }^{\circ} \mathrm{C}$ & 53.0000 & 81.0000 & 162.0000 \\
Fire point ${ }^{\circ} \mathrm{C}$ & 59.0000 & 88.0000 & 173.0000 \\
Gross calorific value $(\mathrm{kJ} / \mathrm{kg})$ & $44,680.0000$ & $43,663.0000$ & $40,610.0000$ \\
Cetane number & 51.0000 & 51.3000 & 52.0000 \\
\hline
\end{tabular}

Table 2. Fatty acid composition of biodiesel

\begin{tabular}{llllr}
\hline Type & \multicolumn{3}{c}{} & MECSO \\
\hline Unsaturatd & 1. & Fatty acid & $18: 1$ & 38.34 \\
& 2. & Linoleic & $18: 2$ & 33.87 \\
Saturated & 3. & Palmitoleic & $16: 1$ & $<0.01$ \\
& 4. & Lauric & $12: 0$ & $<0.01$ \\
& 5. & Palmitic & $16: 0$ & 21.87 \\
& 6. & Stearic & $18: 0$ & 4.12 \\
& 7. & Arachidic & $20: 0$ & 0.46 \\
& 8. & Myristic & $14: 0$ & 0.40 \\
\hline
\end{tabular}


Table 3. Specifications of the test engine

\begin{tabular}{ll}
\hline Make and model & $:$ Kirloskar TAF 1 \\
\hline Type & air cooled, direct injection \\
Bore stroke & $: 87.5 \times 110 \mathrm{~mm}$ \\
Compression ratio & $: 17.5: 1$ \\
Swept volume & $: 661 \mathrm{~cm}^{3}$ \\
Connecting rod length & $: 220 \mathrm{~mm}$ \\
Rated power & $: 4.4 \mathrm{~kW}$ \\
Rated speed & $: 1500 \mathrm{rpm}$ \\
Start of injection & $: 23^{\circ} \mathrm{BTDC}$ \\
Injection pressure & $: 200 \mathrm{bar}$ \\
\hline
\end{tabular}

\section{RESULTS}

\subsection{Performance Characteristics}

Significant engine performance parameters such as BTE and BSFC are evaluated for MECSO and diesel. The $\mathrm{BSFC}$ is an ideal parameter for comparing the engine performance of fuels having different calorific values and specific gravities. BSFC is the ratio between the mass flow rate of the tested fuel and effective power.

Figure 2 shows the BSFC variation of the biodiesel and its blends with respect to brake power of the engine. The BSFC of the engine with neat MECSO (B100) is higher when compared to B25, B50, B75 and diesel at all loads. The lowest BSFC's are 0.29, 0.31, $0.32,0.34$ and $0.36 \mathrm{~kg} / \mathrm{kW}$ h for B0, B25, B50, B75 and $\mathrm{B} 100$ respectively. This may be due to lower heating value, higher viscosity and density of MECSO. The primary reason is, increase in BSFC with increase in fuel blends is the additional consumption of biodiesel fuel by the test engine in order to maintain constant power output (Subramaniam et al., 2013).

Brake Thermal Efficiency (BTE) is the ratio between the power output and the energy introduced through fuel injection, the latter being the product of the injected fuel mass flow rate and the lower heating value. The brake thermal efficiency plots in Fig. 3 show an increase of brake thermal efficiency with an increase in the engine load as the amount of diesel in the blend increases. Even a small quantity of diesel in the blend improves the performance of the engine. The brake thermal efficiency of the B25 blend was better than other blends, which is very close to diesel. This is due to reduction in viscosity which leads to improved atomization, vaporization and combustion. Due to a faster burning of biodiesel in the blend, the thermal efficiency improved. The value is $27.92 \%$ as against $28.56 \%$ for diesel at $100 \%$ load.
The variation of exhaust gas temperature with brake power for diesel, MECSO and its blends are shown in Fig. 4. Exhaust gas temperature increases with the increase in percentage of MECSO in the blend. But it is observed that the exhaust temperature of B25 is nearer to diesel. Since the viscosity of B25 is closer to that of diesel, it improves the combustion process compared to B100 and other blends. Also, the compounds with higher molecular weight present in the MECSO burn at a later stage of combustion, increasing the combustion temperature and exhaust temperature. However, for the other blends and B100 the temperature is high.

\subsection{Emission Characteristics}

Figure 5 shows the variations of $\mathrm{CO}$ emission with respect to brake power of the engine. The air-fuel mixing process is affected by the difficulty in atomization of biodiesel due to its higher viscosity.

Also, the resulting locally rich mixtures of biodiesel cause more $\mathrm{CO}$ to be produced during combustion. However, biodiesel which contains more number of oxygen atoms leads to more complete combustion. At low and middle engine loads, the percentage of $\mathrm{CO}$ emissions of biodiesel and its blends are higher compared to diesel. This may be due to relatively poor atomization and lower volatility of biodiesel. As a result, some of the fuel droplets may not get burned. When these unburned droplets mix with the hot combustion gases, oxidation reactions occur, but do not have enough time to undergo complete combustion. At high engine load, the percentage of $\mathrm{CO}$ emission of $\mathrm{B} 100$ is 0.11 but the percentage of $\mathrm{CO}$ emission of $\mathrm{B} 25$, $\mathrm{B} 50$ and $\mathrm{B} 75$ are $0.07,0.08$ and 0.09 respectively. It vividly indicates that the combustion efficiency improves with the blend of MECSO with diesel and reduction in $\mathrm{CO}$ emission when compared to neat diesel except B100. Since the increase in the quantity of diesel in the blend improves the performance from the emission point of view, the blend ratio is decided based on the amount of diesel to be replaced or the level of emission that can be tolerated.

The variation of $\mathrm{HC}$ emission with brake power is shown in Fig. 6. The emission of HC decreases as the diesel is substituted by biodiesel. It is clear from the figure that an increase in biodiesel percentage leads to decrease in the $\mathrm{HC}$ emission. Cetane number of biodiesel is higher than diesel, due to this it exhibits shorter delay period, which contributes to better combustion of fuel resulting in low emission of $\mathrm{HC}$. 
Another reason can be the oxygen molecules present in the structure of biodiesel, which helps in complete combustion of the fuel and hence decreases $\mathrm{HC}$ emission. At lower loads, the blends containing a higher percentage of diesel will have higher $\mathrm{HC}$ emission. It may be due to lower viscosity of the higher percentage of diesel in the blends and a larger diesel dispersion region in the combustion chamber. At full load, diesel had highest $\mathrm{HC}$ emission of $35 \mathrm{ppm}$ where as for B100 there was a reduction of $14.28 \% \mathrm{HC}$ emission.

The variation of $\mathrm{NO}_{\mathrm{x}}$ with brake power for diesel, biodiesel and its blends are shown in Fig. 7. Three factors that affect the formation of $\mathrm{NO}_{\mathrm{x}}$ in the cylinder are oxygen content, combustion flame temperature and reaction time. $\mathrm{NO}_{\mathrm{x}}$ emissions of biodiesel and its blends are slightly higher than those of diesel fuel. The higher temperature of combustion and the presence of oxygen with biodiesel cause higher $\mathrm{NO}_{\mathrm{x}}$ emissions, especially at high engine loads. $\mathrm{NO}_{\mathrm{x}}$ emissions were found to increase due to the presence of extra oxygen in the molecules of biodiesel blends (Nabi et al., 2009).

However, the biodiesel with higher cetane number had comparable $\mathrm{NO}_{\mathrm{x}}$ emissions with the diesel fuel. A higher cetane number would result in a shortened ignition delay period, thereby allowing less time for the air-fuel mixing before the pre-mixed combustion phase. Consequently, a weaker mixture would be generated and burnt during the premixed combustion phase resulting in relatively reduced $\mathrm{NO}_{\mathrm{x}}$ formation. From the figure, it is clear that at full load, $\mathrm{NO}_{\mathrm{x}}$ emission for $\mathrm{B} 100$ was $23.8 \%$ higher than that of diesel whereas for $\mathrm{B} 25$, the $\mathrm{NO}_{\mathrm{x}}$ emission was $3.5 \%$ higher. $\mathrm{NO}_{\mathrm{x}}$ emission is the most harmful gaseous emissions from the engines; the reduction of it is always the target of engine researchers and engine manufacturers. Reduction of $\mathrm{NO}_{\mathrm{x}}$ with biodiesel may be possible with the proper adjustment of injection timing and by introducing Exhaust Gas Recirculation (EGR) or Selective Catalytic Reduction technology (SCR).

Figure 8 shows the variation of smoke density with brake power for diesel, biodiesel and its blends. There is a significant reduction in smoke emission of $21 \%$ for B100 at full load compared to diesel because of its oxygenated nature. But at low and middle engine loads the smoke density is higher than diesel. This is due to the high viscosity of biodiesel, which results in poor atomization and locally rich mixtures at part load operations. But at high engine load, smoke density of all biodiesel blends is lower than diesel fuel. Smoke is mainly produced in the diffusive combustion phase; the oxygenated fuel blends lead to an improvement in diffusive combustion for the B25 blend. Reduction in smoke emission of about $5.4 \%$ is recorded at full load for the B25 blend. Another reason of smoke reduction, when using biodiesel is due to the lower $\mathrm{C} / \mathrm{H}$ ratio and absence of aromatic compounds as compared to diesel. The carbon content in biodiesel is lower than diesel fuel. The more carbon a fuel molecule contains, the more likely is to produce soot. Conversely, higher oxygen content in the biodeisel leads to lower soot formation (Xue et al., 2011).

\subsection{Combustion Characteristics}

Figure 9 shows the variation of cylinder pressure with crank angle for diesel, biodiesel and its blends at $1500 \mathrm{rpm}$ and full load conditions. Peak pressure mainly depends upon the combustion rate in the initial stages, which is influenced by the fuel taking part in uncontrolled heat release phase. The combustion process of test fuel is similar, consisting of a phase of premixed combustion followed by a phase of diffusion combustion. Premixed combustion phase is controlled by the ignition delay period and spray envelope of the injected fuel (Devan and Mahalakshmi, 2009a). Therefore, the viscosity and volatility of the fuel have a very important role to increase atomization rate and to improve air-fuel mixing formation. The cylinder peak pressure because of the high viscosity and low volatility of biodiesel and its blends is slightly lowerer than that of diesel fuel. It is observed that the peak pressures of $67.23,67.19,66.49,65.75$ and 65.18 bar were recorded for diesel fuel, B25, B50, B75 and B100 respectively. However, the cylinder peak pressure of biodiesel fuels was close to diesel due to the improvement in the preparation of air-fuel mixture as a result of low fuel viscosity (Devan and Mahalakshmi, 2009b; Ozsezen et al., 2009).

The variation of heat release rate with crank angle at full load for diesel, biodiesel and its blends are shown in Fig. 10. It is observed from the results that the heat release rate for biodiesel and its blends are lower compared to diesel fuel. However B25 gives more heat release rate than other blends. On the other hand, peak heat release rate for $\mathrm{B} 100$ is low compared to B25 and this may be due to lower volatility and higher viscosity of B100 (Prabhu et al., 2013). The maximum heat release rate of diesel fuel, $\mathrm{B} 25, \mathrm{~B} 50, \mathrm{~B} 75$ and $\mathrm{B} 100$ is $114.42,111.76,106.21,98.39$ and $89.66 \mathrm{~kJ} / \mathrm{m}^{3} \mathrm{deg}$ respectively. A Closer analysis of the heat release rate at higher engine load showed proper utilization of B25 inside the combustion chamber of the engine. 
Vijayaraj, K. and A.P. Sathiyagnanam / American Journal of Applied Sciences 11 (10): 1819-1829, 2014

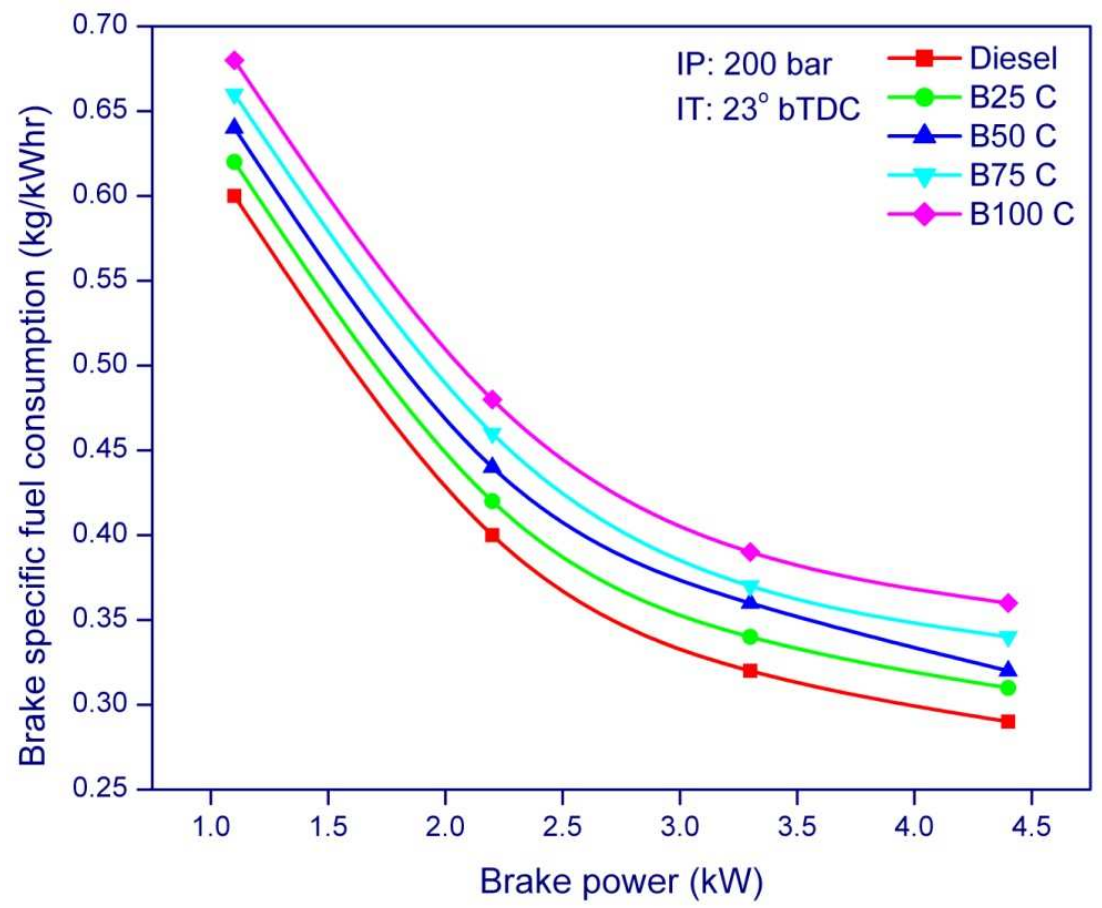

Fig. 2. Variation of BSFC with BP

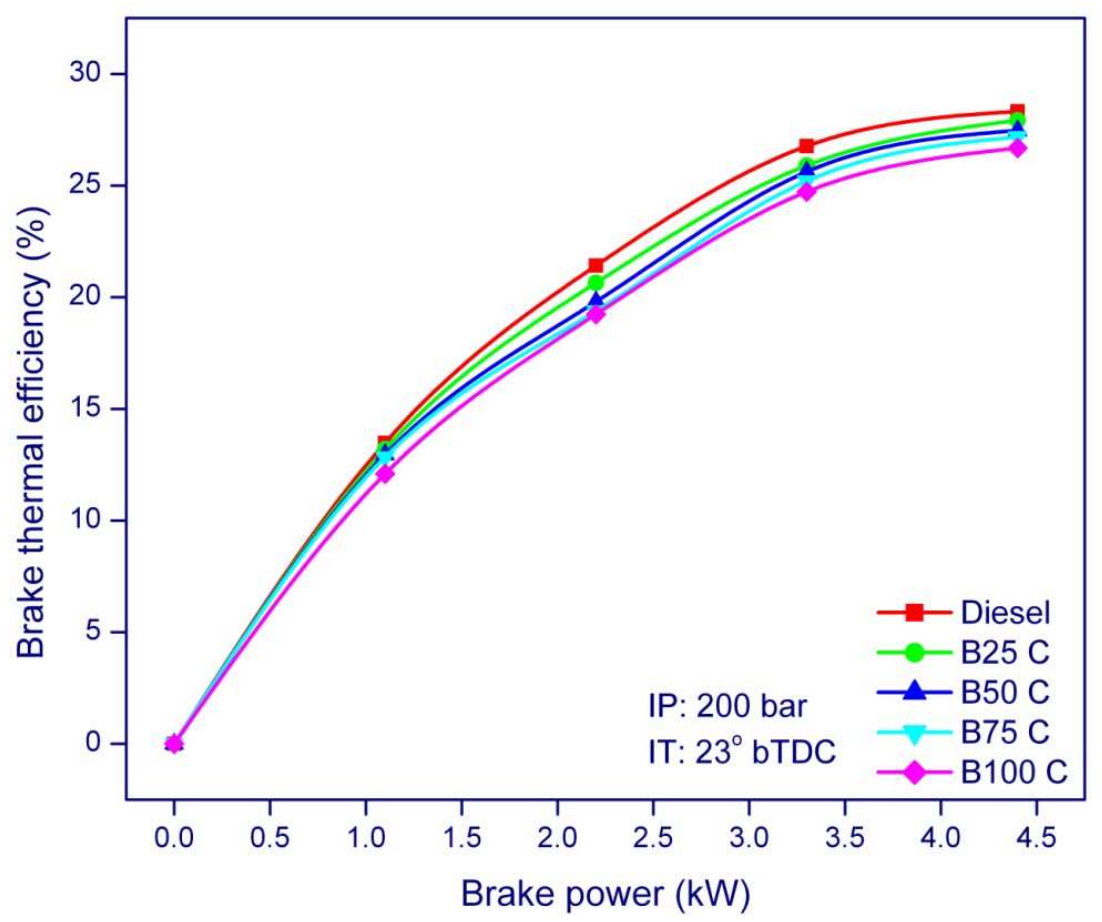

Fig. 3. Variation of brake thermal efficiency with BP 
Vijayaraj, K. and A.P. Sathiyagnanam / American Journal of Applied Sciences 11 (10): 1819-1829, 2014

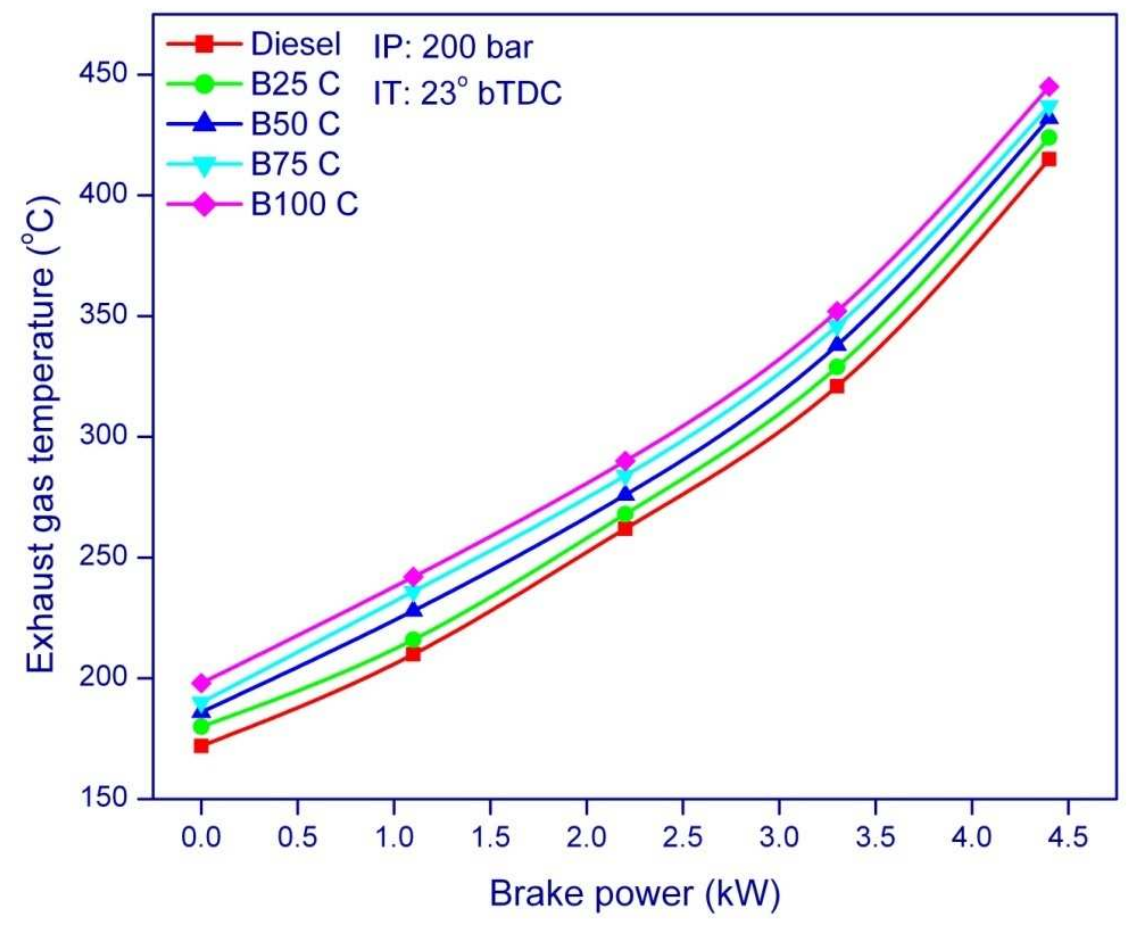

Fig. 4. Variation of exhaust gas temperature with BP

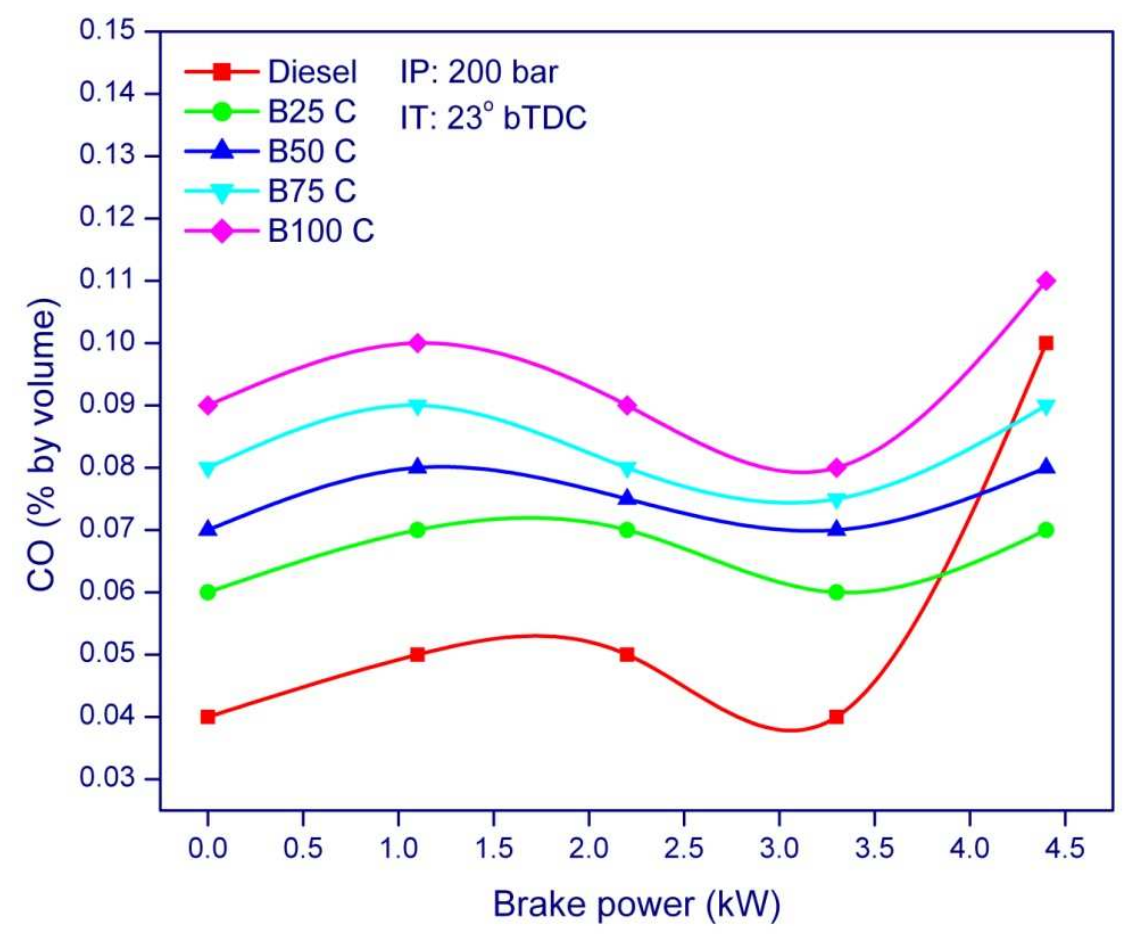

Fig. 5. Variation of carbon monoxide with BP 
Vijayaraj, K. and A.P. Sathiyagnanam / American Journal of Applied Sciences 11 (10): 1819-1829, 2014

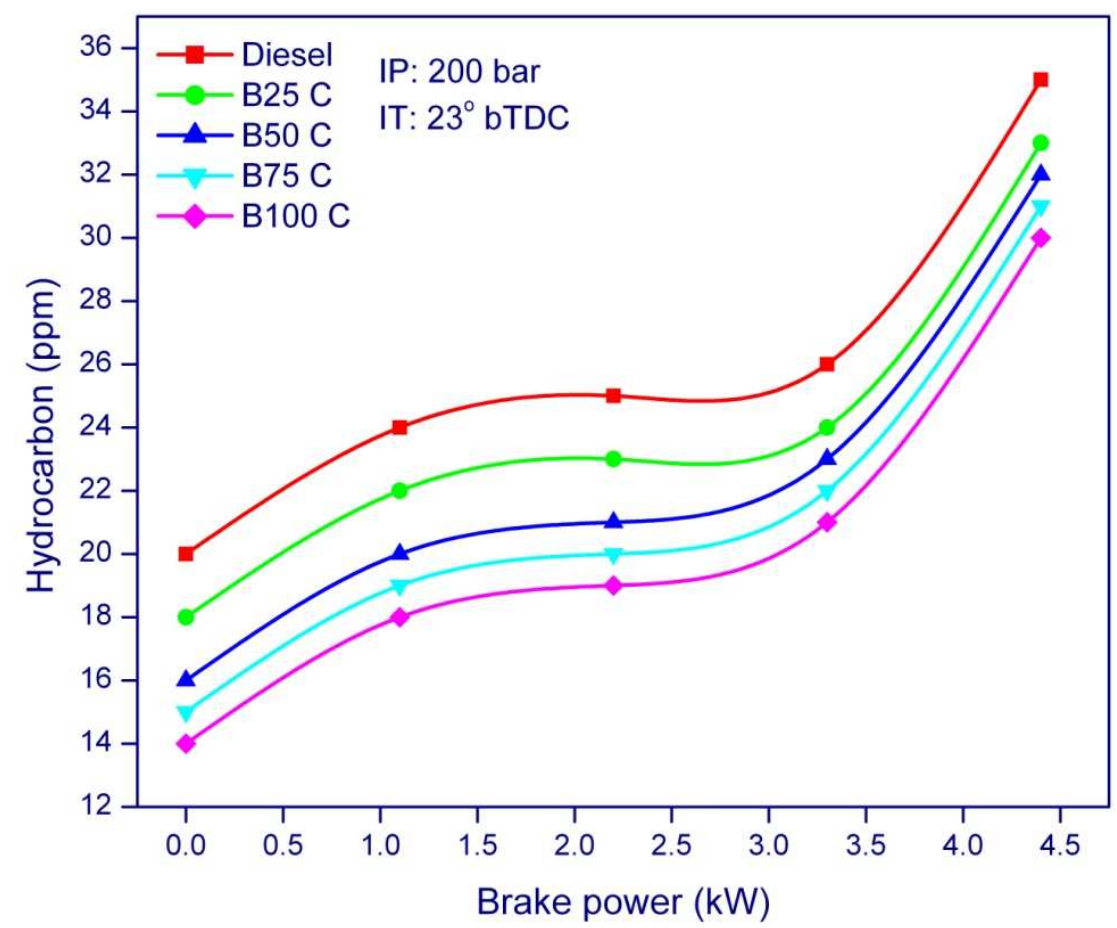

Fig. 6. Variation of hydrocarbon with BP

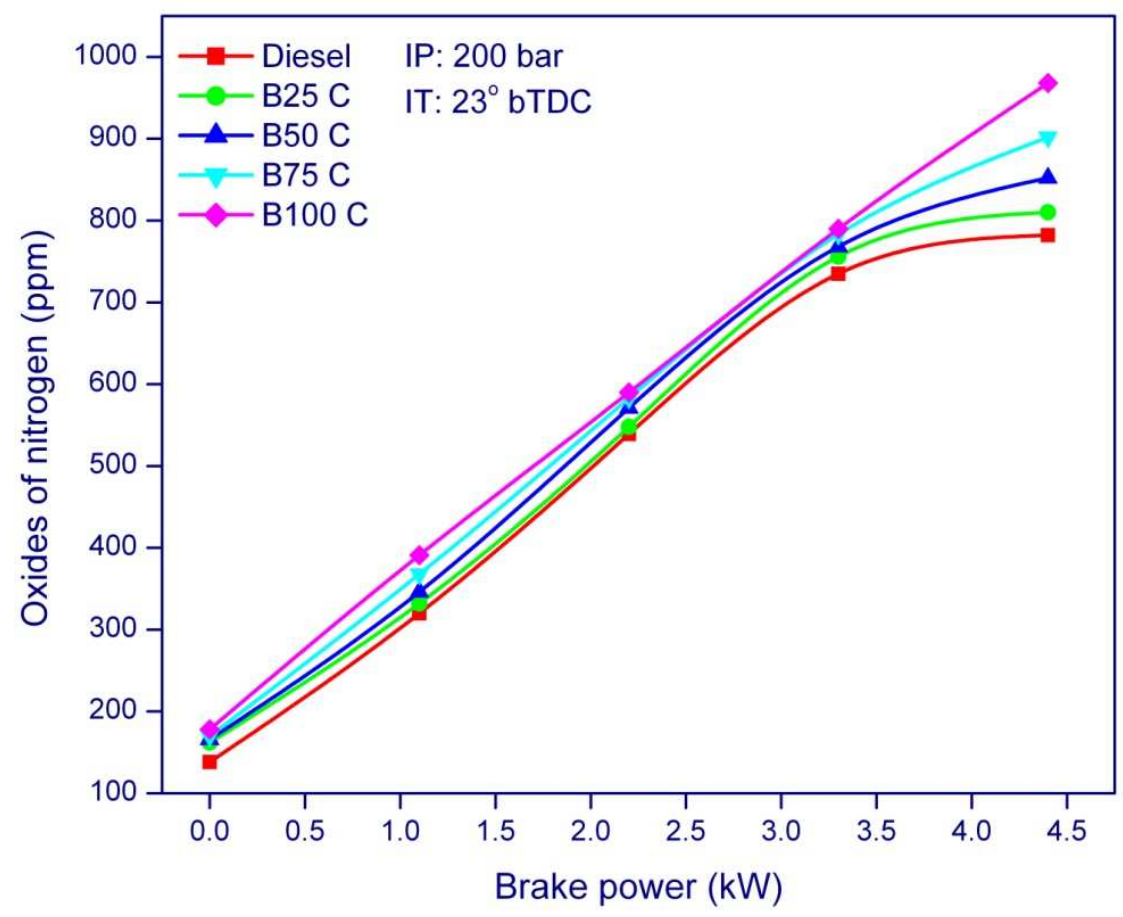

Fig. 7. Variation of oxides of Nitrogen with BP 
Vijayaraj, K. and A.P. Sathiyagnanam / American Journal of Applied Sciences 11 (10): 1819-1829, 2014

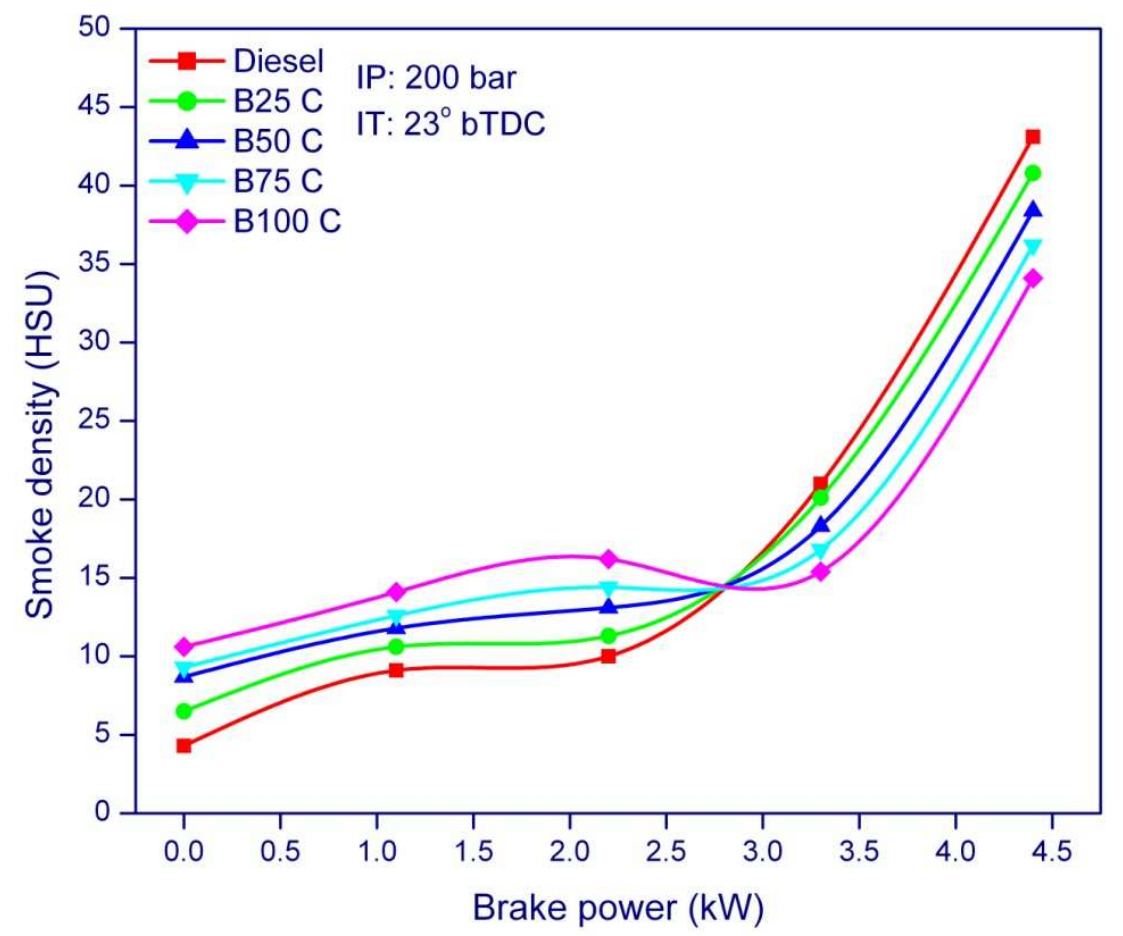

Fig. 8. Variation of smoke density with BP

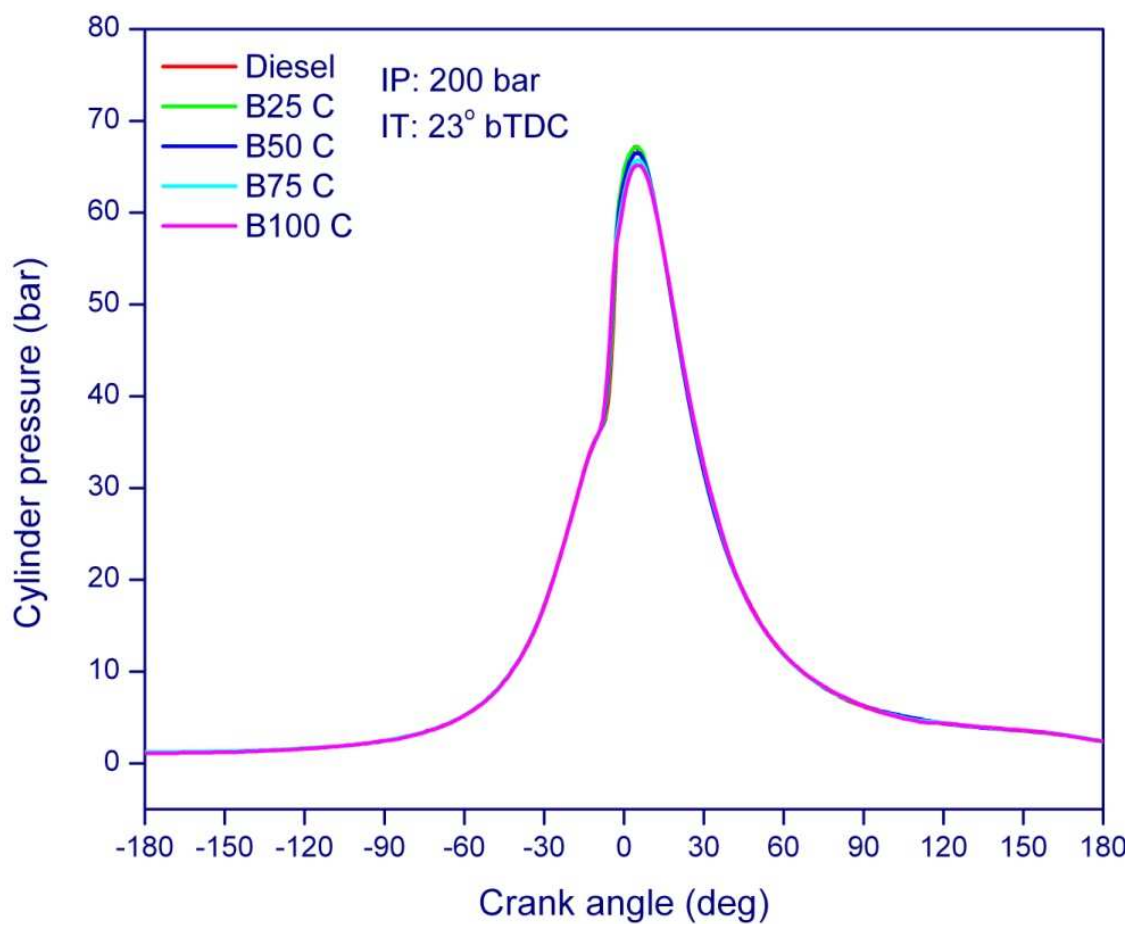

Fig. 9. Variation of cylinder pressure with crank angle 


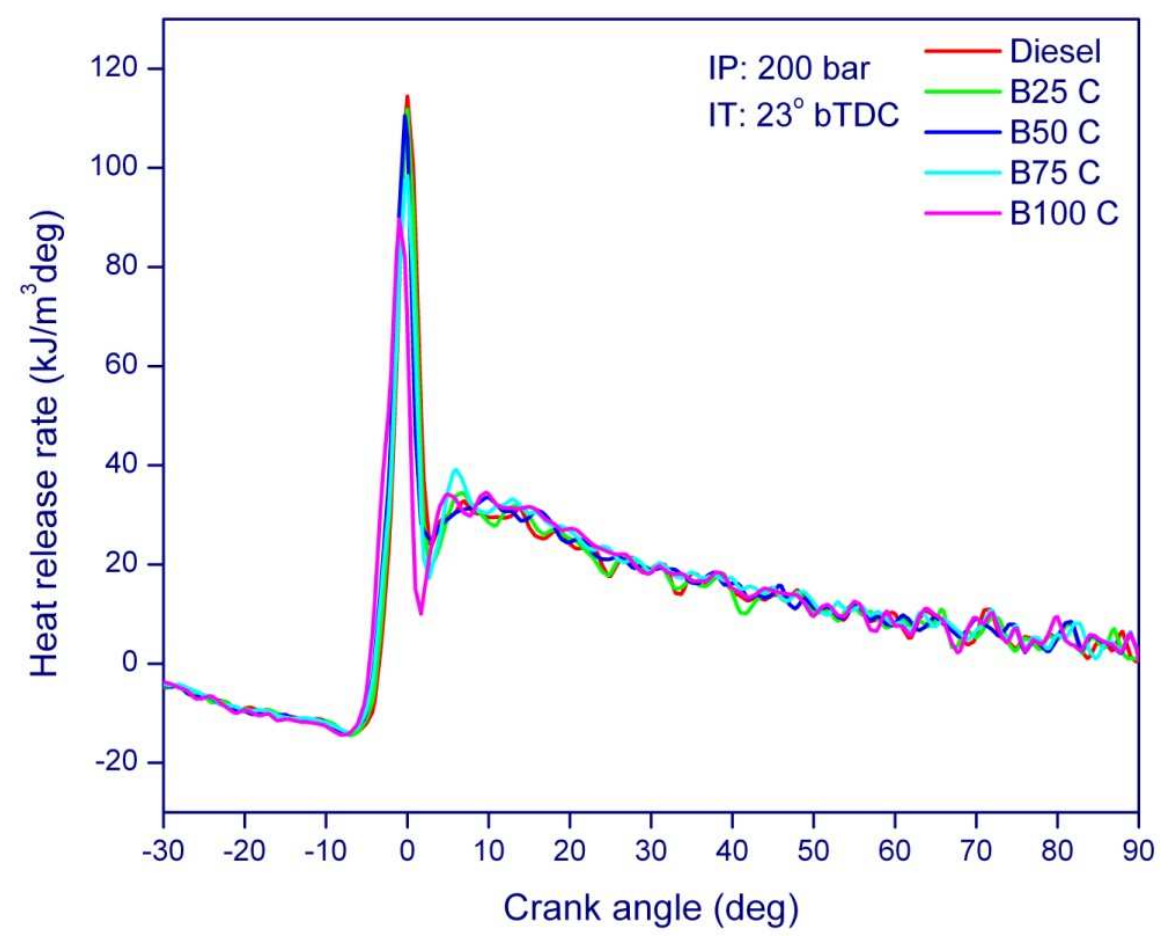

Fig. 10. Variation of heat release rate with crank angle

\section{DISCUSSION}

Fuel saving and exhaust emissions reduction are the key concern of this study. As per the results, lower brake specific fuel consumption and higher brake thermal efficiency are observed for B25 than other blends. Exhaust emission like smoke is less due to, less carbon atoms, lack of aromatics compounds, more oxygen content and better atomization of the blended fuel. Low $\mathrm{HC}$ and high $\mathrm{NO}_{\mathrm{x}}$ emissions are by the fact that oxygen-rich concentration and lower cetane number of the biodiesel. Higher heat release rate and higher cylinder pressure are mainly due to the amount of fuel accumulated in the delay period, combustion rate in the initial stages of premixed combustion and complete combustion of the air-fuel mixture.

\section{CONCLUSION}

In the present investigation, the performance, emission and combustion characteristics of a direct injection, compression ignition engine fuelled with methyl ester of cotton seed oil and its blends have been analyzed and compared with diesel fuel. The biodiesel is produced from raw cotton seed oil by a method of transesterification. The tests for properties of biodiesel demonstrate that almost all the important properties of biodiesel are in close agreement with the diesel fuel. Thus the diesel engine can perform satisfactorily on biodiesel and its blends with diesel fuel without any engine modifications. The results of the present work are summarized as follows:

- The BSFC increases with increase in percentage of biodiesel in the blends due to lower heating value of biodiesel

- The BTE of B25 is closer to diesel at all loads

- Except B100, the emission of CO for B25, B50 and B75 are lower than diesel at full load

- It is observed that there is a significant reduction of $\mathrm{HC}$ for biodiesel and its blends at all engine loads

- The emission of $\mathrm{NO}_{\mathrm{x}}$ is higher than diesel for biodiesel and its blends, but for B25 slight increase of only $3.5 \%$ at full load

- Reduction of smoke emission for biodiesel and its blends than diesel at full load, whereas for B25 reduction is observed at all engine loads. Compared to diesel, decrease in smoke emission of $5.4 \%$ is observed for B25 at full load 
- The combustion starts earlier for biodiesel and its blends than diesel. The peak cylinder pressure and heat release rate of biodiesel and its blends are lower than diesel

\section{ACKNOWLEDGMENT}

We thank the management of Sri Venkateswara College of Engineering, Sriperumpudur and Tamilnadu, India for providing the necessary experimental setup to perform this research work.

\section{ADDITIONAL INFORMATION}

\subsection{Funding Information}

NIL

\subsection{Author's Contributions}

My co-author Dr. A.P. Sathiyagnanam has guided me in preparing this manuscript.

\subsection{Ethics}

This is my original research work and there are no ethical issues involved.

\section{REFERENCES}

Devan, P.K. and N.V. Mahalakshmi, 2009a. Performance, emission and combustion characteristics of poon oil and its diesel blends in a DI diesel engine. Fuel, 88: 861-867. DOI: 10.1016/j.fuel.2008.11.005

Devan, P.K. and N.V. Mahalakshmi, 2009b. Study of the performance, emission and combustion characteristics of a diesel engine using poon oilbased fuels. Fuel Process Technol., 90: 513-519. DOI: 10.1016/j.fuproc.2009.01.009

Jain, S. and M.P. Sharma, 2011. Biodiesel production from jatropha oil. Renewable Sustainable Energy Rev., 14: 3140-7.

Nabi, N., M. Rahman and S. Akhter, 2009. Biodiesel from cotton seed oil and its effect on engine performance and exhaust emissions. Applied Thermal Eng., 29: 2265-2270. DOI: 10.1016/j.applthermaleng.2008.11.009
Ozsezen, A.N., M. Canakci, A. Turkcan and C. Sayin, 2009. Performance and combustion characteristics of a DI diesel engine fueled with waste palm oil and canola oil methyl esters. Fuel, 88: 629-636. DOI: 10.1016/j.fuel.2008.09.023

Qi, D.H., L.M. Geng, H. Chen, Y.Z.H. Bian and J. Liu et al., 2009. Combustion and performance evaluation of a diesel engine fueled with biodiesel produced from soybean crude oil. Renew Energy, 34: 2706-2713. DOI: 10.1016/j.renene.2009.05.004

Singh, S., 2012. Study of various methods of biodiesel production and properties of biodiesel prepared from waste cotton seed oil and waste mustard oil. Thesis of M.E.in thermal engineering, Thapar University.

Subramaniam, D., A. Murugesan and A. Avinash, 2013. A comparative estimation of $\mathrm{CI}$ engine fuelled with methyl esters of punnai, neem and waste cooking oil. Int. J. Energy Environ., 4: 859-870.

Sylvester, C.I. and E.I. Ohimain, 2013. The challenge of biodiesel production from oil palm feedstock in Nigeria. Greener J. Biol. Sci., 3: 001-012.

Shereena, K.M. and T. Thangaraj, 2009. Biodiesel: An alternative fuel produced from vegetalbe oils by transesterification. Elect. J. Biol., 3: 67-74.

Prabhu, L., S. Sathish Kumar, M. Prabhahar and K. Rajan, 2013. Combustion, performance and emission characteristics of diesel engine with neem oil methyl ester and its diesel blends. Am. J. Applied Sci., 10: 810-818. DOI: 10.3844/ajassp.2013.810.818

Xue, J., T.E. Grift and A.C. Hansen, 2011. Effect of biodiesel on engine performances and emissions. Renewable Sustainable Energy Rev., 15: 10981116. DOI: $10.1016 /$ j.rser.2010.11.016 